\title{
Manufacture of Third-Generation Lentivirus for Preclinical Use, with Process Development Considerations for Translation to Good Manufacturing Practice
}

\author{
Carolina Gándara, ${ }^{1,2}$ Valerie Affleck, ${ }^{1,2}$ and Elizabeth Ann Stoll ${ }^{1,2, *}$ \\ ${ }^{1}$ Institute of Neuroscience and ${ }^{2}$ Controlling Abnormal Network Dynamics using Optogenetics (CANDO) Consortium, Newcastle University, \\ Newcastle upon Tyne, United Kingdom.
}

Lentiviral vectors are used in laboratories around the world for in vivo and ex vivo delivery of gene therapies, and increasingly clinical investigation as well as preclinical applications. The third-generation lentiviral vector system has many advantages, including high packaging capacity, stable gene expression in both dividing and post-mitotic cells, and low immunogenicity in the recipient organism. Yet, the manufacture of these vectors is challenging, especially at high titers required for direct use in vivo, and further challenges are presented by the process of translating preclinical gene therapies toward manufacture of products for clinical investigation. The goals of this paper are to report the protocol for manufacturing hightiter third-generation lentivirus for preclinical testing and to provide detailed information on considerations for translating preclinical viral vector manufacture toward scaled-up platforms and processes in order to make gene therapies under Good Manufacturing Practice that are suitable for clinical trials.

Keywords: gene therapy, GMP manufacture, lentivirus, HEK293T, virus, viral vector

\section{INTRODUCTION}

THE THIRD-GENERATION lentiviral vector design and original protocol for high-titer virus production was developed in the Naldini and Trono laboratories. ${ }^{1-3}$ In the 20 years since, lentiviral vectors have become commonly used for gene delivery for preclinical research applications and are now becoming the vector of choice for in vivo and ex vivo delivery of genetic material in gene and cell therapies, ${ }^{4,5}$ having been made and used for clinical trials in human patients. ${ }^{6-9}$

This gene therapy delivery system is wellcharacterized, effectively delivers genetic material into dividing and nondividing cells, stably integrates into the host cell genome to maintain long-term expression in target cells, and delivers larger amounts of genetic material than other vector systems. Furthermore, third-generation lentiviruses are thought to be nonpathogenic and non-immunogenic, although long-term investigations are still underway. Guidance on broaching this and related subjects with regulatory authorities in the course of developing a clinical trial plan is available. ${ }^{10}$

The third-generation lentiviral vectors described here are considered to be replicationincompetent and self-inactivating vectors, due to the number of essential genes that have been deleted from the third-generation lentiviral packaging system. ${ }^{11}$ These third-generation lentivector systems have a number of additional safety features over the second-generation: the viral tat gene, which is essential for replication of wild-type human immunodeficiency virus type 1 (HIV-1), has been deleted; vector packaging functions have been separated onto three separate plasmids instead of two in order to reduce risk of recombination during plasmid amplification and viral vector manufacture; an altered 3' LTR renders the vector "selfinactivating" in order to prevent integrated genes from being repackaged; and a heterologous coat protein (e.g., VSV-G) is used in place of the native

${ }^{*}$ Correspondence: Dr. Elizabeth Ann Stoll, Institute of Neuroscience, Newcastle University, Framlington Place, Newcastle upon Tyne, NE2 4HH, United Kingdom. E-mail: izi.stoll@gmail.com

(c) Carolina Gándara et al. 2018; Published by Mary Ann Liebert, Inc. This is an Open Access article distributed under the terms of the Creative Commons Attribution License, which permits unrestricted use, distribution, and reproduction in any medium, provided the original work is properly cited. 
HIV-1 envelope protein. VSV-G is the most popular glycoprotein to date for pseudotyping lentiviral vectors, as these modified particles can transduce a wider range of cell types and have a lot more stability, which allowed these vectors to be concentrated by ultracentrifugation to reach higher titers. ${ }^{12}$

Preclinical gene therapies made with substantially similar lentiviral vectors to the clinical material can be used for efficacy testing in various model systems, in vitro and in vivo. Protocols for small-scale production of second-generation lentiviral vectors, ${ }^{13,14}$ as well as more general manufacturing reviews ${ }^{15}$ and large-scale Good Manufacturing Practice (GMP)grade methods ${ }^{16-22}$ have been published. This report provides a useful, open-access protocol for the production of high-titer third-generation lentivirus, with tips for translating preclinical research-grade procedures toward GMP for the production of viralmediated gene therapies for clinical investigation. In this protocol, HEK293T are used as producer cells, but COS-7 cells have also been successfully used for lentiviral manufacture. ${ }^{14}$

The goals of this report are to share the Standard Operating Protocol (SOP) for preclinical lentivirus production and the process development considerations for clinical-grade lentivirus manufacture, where the quality of the product, consistent production, and GMP compliance must be met, as well as the requirements set in the relevant manufacturing and clinical trial authorizations. A broad overview of processes related to the manufacture of GMP lentiviral vector-based gene therapies is shown in Fig. 1; specific considerations for converting preclinical viral manufacturing protocols and platforms to scaled-up GMP manufacture are provided after the protocol itself and the troubleshooting section.

\section{MATERIALS HEK293T producer cell line}

HEK 293 cells were generated in 1973 by isolation and subsequent adenoviral-mediated transformation of human embryonic kidney cell cultures in Alex van der Eb's laboratory in Leiden, The Netherlands. The 293T cells are derived from HEK 293 cells but stably express the SV40 large T antigen, which can bind to SV40 enhancers-ofexpression vectors to increase protein production.

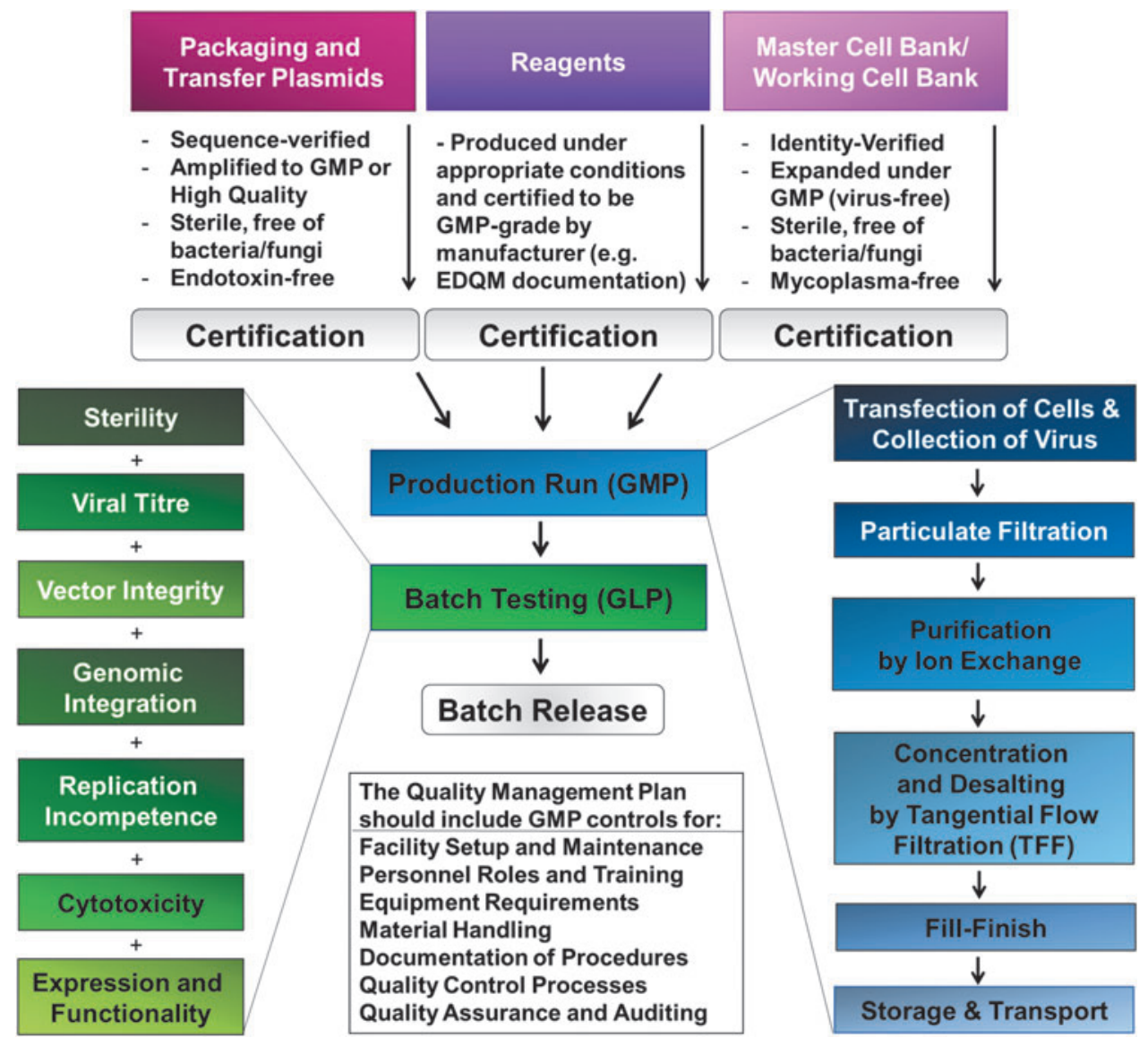

Figure 1. Process for lentiviral production under Good Manufacturing Practice. 
This cell line is easy to grow, transfects readily, ectopically expresses genes, and has been widely used in research laboratories for many years. HEK293T are also used as cell factories to generate lentiviral vectors ${ }^{23}$ (as described here in "Experimental Procedures").

\section{Plasmids encoding the genetic payload and viral packaging components}

The transfer vector should contain the desired transgene(s) and other components required for viral integration and expression in the host genome. The full sequence justification of $\mathrm{pMUH}$, a versatile third-generation lentivector, ${ }^{10}$ is given in Table 1. This and similar third-generation lentivector trans- fer plasmids contain multiple cloning sites for insertion of target genes, as well as a fluorescent reporter or selection marker for preclinical use. Using this vector plasmid, the promoter driving gene expression, and up to three genes, can easily be swapped to achieve flexibility for preclinical viral vector development and to achieve the leanest lentivector construct sequence for producing a targeted gene therapy.

It is inadvisable for fluorescent reporter proteins to be included in viral vectors used for gene therapies in humans, since these proteins are thought to be immunogenic. ${ }^{24}$ However, efficacy tests in cell cultures or animal models can make use of them. Furthermore, European regulatory guidance urges

Table 1. $p M U H$ third-generation lentivector plasmid

\begin{tabular}{|c|c|c|c|}
\hline Location & Size $(b p)$ & Feature & Description and justification \\
\hline $235 \ldots 415$ & 181 & $5^{\prime}$ LTR (truncated) & $\begin{array}{l}\text { Truncated 5' LTR from HIV-1. Essential for viral transcription, reverse transcription, and } \\
\text { integration. }\end{array}$ \\
\hline $462 \ldots 587$ & 126 & HIV-1 $\Psi$ & Packaging signal of HIV-1. Essential for transfer plasmid packaging. \\
\hline $1080 \ldots 1313$ & 234 & RRE & $\begin{array}{l}\text { Essential for Rev-dependent mRNA export from the nucleus to the cytoplasm of viral } \\
\text { transcripts. }\end{array}$ \\
\hline $1840 \ldots 1957$ & 118 & сPPT/CTS & cPPT/CTS of HIV-1. Improves vector integration and transduction efficiency. \\
\hline $3272 \ldots 3979$ & 708 & mCherry & $\begin{array}{l}\text { monomeric derivative of DsRed fluorescent protein. Indicates transgene expression. Can } \\
\text { be replaced or removed for clinical trials. }\end{array}$ \\
\hline $3989 \ldots 4045$ & 57 & P2A & $\begin{array}{l}\text { 2A peptide from porcine teschovirus-1 polyprotein. Self-cleaving peptide to separate co- } \\
\text { expressed proteins. Can be replaced or removed for clinical trials. }\end{array}$ \\
\hline $4052 \ldots 4087$ & 36 & MCS & Contains multiple restriction sites used for transgenes insertion. \\
\hline $4097 \ldots 4150$ & 54 & T2A & $\begin{array}{l}\text { 2A peptide from Thosea asigna virus capsid protein. Self-cleaving peptide to separate co- } \\
\text { expressed proteins. Can be replaced or removed for clinical trials. }\end{array}$ \\
\hline $5178 \ldots 5299$ & 122 & SV40 poly(A) signal & Important for the nuclear export, translation, and stability of mRNA. \\
\hline $5339 \ldots 5474$ & 136 & SV40 ori & $\begin{array}{l}\text { Essential for transfer plasmid maintenance in mammalian cells during viral vector } \\
\text { manufacture. }\end{array}$ \\
\hline $5495 \ldots 5513$ & 19 & T7 promoter & Promoter for bacteriophage T7 RNA polymerase. Plasmid features. \\
\hline $5523 \ldots 5539$ & 17 & M13 fwd & $\begin{array}{l}\text { Common sequencing primer, one of multiple similar variants. Used for sequencing } \\
\text { purposes. }\end{array}$ \\
\hline $5681 \ldots 6136$ & 456 & f1 ori & Arrow indicates direction of $(+)$ strand synthesis. Plasmid features. \\
\hline $6162 \ldots 6266$ & 105 & AmpR promoter & $\begin{array}{l}\text { Ampicillin resistance gene promoter for plasmid selection in bacteria; will be substituted } \\
\text { for clinical-grade plasmid per EMA NOTE CPMP/BWP/3088/99 and Ph. Eur., Monograph } \\
5.14 \text {. }\end{array}$ \\
\hline $6267 \ldots 7127$ & 861 & AmpR & $\begin{array}{l}\text { Ampicillin resistance selectable marker for plasmid selection in bacteria; will be } \\
\text { substituted for clinical-grade plasmid per EMA NOTE CPMP/BWP/3088/99 and Ph. Eur., } \\
\text { Monograph 5.14. }\end{array}$ \\
\hline
\end{tabular}

RSV, Rous sarcoma virus; LTR, long terminal repeat; HIV-1, human immunodeficiency virus type 1; RRE, Rev response element; cPPT/CTS, central polypurine tract and central termination sequence; UbC, human ubiquitin C promoter; MCS, multiple cloning site; WPRE, woodchuck hepatitis virus posttranscriptional regulatory element; SV40 poly(A) signal, SV40 polyadenylation signal; SV40 ori, Simian virus 40 (SV40) origin of replication; f1 ori, f1 bacteriophage origin of replication. 
Table 2. $p R S V-R e v$ packaging plasmid

\begin{tabular}{|c|c|c|c|}
\hline Location & Size $(b p)$ & Feature & Description and Justification \\
\hline $1024 \ldots 1612$ & 589 & ori & $\begin{array}{l}\text { High-copy-number ColE1/pMB1/pBR322/pUC origin of replication. Essential for plasmid replication in } \\
\text { bacteria. }\end{array}$ \\
\hline $1900 \ldots 1921$ & 22 & CAP binding site & Trans-acting transcriptional activator. Plasmid features. \\
\hline $1936 \ldots 1966$ & 31 & lac promoter & Promoter for the E. coli lac operon. Plasmid features. \\
\hline $1974 \ldots 1990$ & 17 & lac operator & Repression region for the $E$. coli lac operon. Plasmid features. \\
\hline $1998 \ldots 2014$ & 17 & M13 rev & Common sequencing primer, one of multiple similar variants. Used for sequencing purposes. \\
\hline $2159 \ldots 2420$ & 262 & RSV promoter & Essential for Rev expression. \\
\hline $2549 \ldots 2899$ & 351 & Rev & $\begin{array}{l}\text { Trans-activating protein to control nuclear export of incompletely spliced mRNAs. Essential to produce } \\
\text { viral structural proteins during viral vector manufacture. }\end{array}$ \\
\hline $2983 \ldots 2999$ & 17 & M13 fwd & Common sequencing primer, one of multiple similar variants. Used for sequencing purposes. \\
\hline $3331 \ldots 3786$ & 456 & f1 ori & $\begin{array}{l}\text { f1 bacteriophage origin of replication; arrow indicates direction of }(+) \text { strand synthesis. Plasmid } \\
\text { features. }\end{array}$ \\
\hline $4068 \ldots 4172$ & 105 & AmpR promoter & Ampicillin resistance gene promoter. Essential for plasmid selection in bacteria. \\
\hline $4173 \ldots 853$ & 861 & AmpR & Ampicillin resistance selectable marker. Essential for plasmid selection in bacteria. \\
\hline
\end{tabular}

careful and well-justified use of antibiotics during plasmid preparation and viral production in order to avoid the cultivation of antibiotic-resistant strains of bacteria. Such considerations should be taken into account when designing the specific characteristics of a transfer vector.

\section{Packaging plasmids}

The packaging genes used for preclinical thirdgeneration lentivirus manufacture are contained on three separate plasmids, which are co-transfected into the producer cell line along with the transfer vector. These three plasmids are described in Tables 2-4. The four plasmids are shared among academic laboratories, but would have to be specifically licensed for use in clinical-grade lentivirus manufacture.

\section{pRSV-Rev (Addgene \#12253, from the laboratory of Prof. Didier Trono)}

The sequence of the pRSV-Rev plasmid is described in Table 2. This is a cDNA expressing plasmid in which the joined second and third exons of HIV-1 rev is under the transcriptional control of RSV $\mathrm{U} 3$ promoter. Rev is a trans-activating protein that is essential to the regulation of HIV-1 protein expression. A nuclear localization signal is encoded in the rev gene, which allows the Rev protein to be transported to the nucleus, where it is involved in the export of unspliced and incompletely spliced mRNAs. In the absence of rev, mRNAs of the HIV-1 late (structural) genes are retained in the nucleus, preventing their translation. HIV-1 regulatory proteins (including $r e v$ ) are translated from completely processed mRNA transcripts, while structural proteins are translated from incompletely spliced transcripts. Completely spliced transcripts are exported from the nucleus to the cytoplasm by the same mechanism as cellular mRNA. However, rev is needed to export incompletely spliced mRNAs in order to produce the viral structural proteins during manufacture.

\section{pMD2.G (Addgene \#12259, from the laboratory of Prof. Didier Trono)}

The sequence of the pMD2.G plasmid encoding Vesicular stomatitis virus glycoprotein is described in Table 3. This cDNA expressing plasmid encodes vesicular stomatitis virus glycoprotein (vsv-g) to coat the envelope of the virus, providing a tropism that allows entry into a broad range of mammalian cell types. Alternative envelopes for lentiviral vectors other than VSV-G have been proposed. The use of different envelopes can be a powerful tool to achieve cell-specific gene delivery. ${ }^{25}$

Table 3. $p M D 2 G$ packaging plasmid

\begin{tabular}{lcll}
\hline Location & Size (bp) & \multicolumn{1}{c}{ Feature } & \\
\hline $1048 \ldots 1442$ & 395 & $\beta$-globin poly(A) & Important for the nuclear export, translation, and stability of mRNA. \\
$1952 \ldots 2540$ & 589 & ori & High-copy-number ColE1/pMB1/pBR322/pUC origin of replication. Essential for plasmid replication in bacteria. \\
$2711 \ldots 3571$ & 861 & AmpR & Ampicillin resistance selectable marker. Essential for plasmid selection in bacteria. \\
$3572 \ldots 3676$ & 105 & AmpR promoter & Ampicillin resistance gene promoter. Essential for plasmid selection in bacteria. \\
$3867 \ldots 4246$ & 380 & CMV enhancer & Human CMV immediate early enhancer. Essential for Rev expression. \\
$4247 \ldots 4450$ & 204 & CMV promoter & Human CMV immediate early promoter. Essential for Rev expression. \\
$4584 \ldots 5059$ & 476 & $\beta$-globin intron & Internally truncated intron from human $\beta$-globin. Improves gene expression. \\
$5134 \ldots 847$ & 1536 & VSV-G & Replaces the native lentiviral Env glycoprotein, providing more stable vectors to transduce a wider set of cells.
\end{tabular}

$\beta$-globin poly(A), human $\beta$-globin polyadenylation signal; CMV, cytomegalovirus; VSV-G, vesicular stomatitis virus $\mathrm{G}$ glycoprotein. 
Table 4. $p M D L g / p R R E$ packaging plasmid

\begin{tabular}{|c|c|c|c|}
\hline Location & Size (bp) & Feature & Description and justification \\
\hline $22 \ldots 401$ & 380 & CMV enhancer & Human CMV immediate early enhancer. Essential for Rev expression. \\
\hline $402 \ldots 605$ & 204 & CMV promoter & Human CMV immediate early promoter. Essential for Rev expression. \\
\hline $739 \ldots 1214$ & 476 & $\beta$-globin intron & Internally truncated intron from human $\beta$-globin. Improves gene expression. \\
\hline $1298 \ldots 2800$ & 1503 & HIV-1 gag & gag protein from HIV-1. Encodes essential viral core proteins. \\
\hline $2593 \ldots 5604$ & 3012 & HIV-1 pol & pol protein from HIV-1. Encodes a set of enzymes essential for viral integration. \\
\hline $5289 \ldots 5406$ & 118 & сPPT/CTS & Improves vector integration and transduction efficiency. \\
\hline $5629 \ldots 5862$ & 234 & RRE & Essential for Rev-dependent mRNA export from the nucleus to the cytoplasm of viral transcripts. \\
\hline $6093 \ldots 6487$ & 395 & $\beta$-globin poly(A) & Important for the nuclear export, translation and stability of mRNA. \\
\hline $6997 \ldots 7585$ & 589 & ori & High-copy-number ColE1/pMB1/pBR322/pUC origin of replication. Essential for plasmid replication in bacteria. \\
\hline $7756 \ldots 8616$ & 861 & AmpR & Ampicillin resistance selectable marker. Essential for plasmid selection in bacteria. \\
\hline $8617 \ldots 8721$ & 105 & AmpR promoter & Ampicillin resistance gene promoter. Essential for plasmid selection in bacteria. \\
\hline
\end{tabular}

pMDLg/pRRE (Addgene \#12251, from the laboratory of Prof. Didier Trono)

The sequence of the $\mathrm{pMDLg} / \mathrm{pRRE}$ plasmid encoding viral core proteins is described in Table 4 . This plasmid encodes gag, which encodes the main structural proteins of the virus, and pol, which encodes the retrovirus-specific enzyme reverse polymerase.

\section{Reagents and consumables}

Reagents used in preclinical manufacture are shown in Supplementary Table S1 (Supplementary Data are available online at www.liebertpub.com/ hgtb). Many of these products are made or sterilized under high-quality conditions, traced from origin, and certified for GMP use.

Consumables, such as conical tubes and tissue culture flasks, used in preclinical virus manufacture, which are made or sterilized under highquality conditions, traced from origin, and certified for GMP use, are suitable for use in GMP manufacture as well as for research purposes.

\section{Instrumentation and equipment}

1. Small incubator $37^{\circ} \mathrm{C}$

2. Large orbital shaker/incubator

3. Bunsen burner

4. Microwave

5. Balance

6. $\mathrm{pH}$ meter

7. Gel electrophoresis and imaging system

8. Blue light transilluminator

9. Vortex mixer

10. DNA spectrophotometer

11. Biological safety cabinet

12. $\mathrm{CO}_{2}$ system

12.1. Tanks

12.2. Regulators

12.3. Hoses

12.4. Changeover unit
13. Incubator $37^{\circ} \mathrm{C}, 5 \% \mathrm{CO}_{2}$

14. Benchtop centrifuges

14.1. Mini (pulse spin, $1.5 \mathrm{~mL}$ tubes)

14.2. Micro ( $1.5 \mathrm{~mL}$ tubes)

14.3. Small ( $50 \mathrm{~mL}$ tubes)

15. Ultracentrifuge

16. Refrigerator $\left(4^{\circ} \mathrm{C}\right)$

17. Freezers $\left(-20^{\circ} \mathrm{C}\right.$ and $\left.-80^{\circ} \mathrm{C}\right)$

18. $\mathrm{N}_{2}$ storage tank

19. Light microscope

20. Bead or water bath

21. Vacuum pump

22. Pipettes

\section{EXPERIMENTAL PROCEDURE Making reagents for cell culture and transfection}

Cell culture medium (containing $10 \%$ fetal bovine serum). In $440 \mathrm{~mL}$ of Dulbecco's modified Eagle's medium containing high glucose, add $50 \mathrm{~mL}$ of fetal bovine serum (FBS; for a final concentration of $10 \%$ ), $5 \mathrm{~mL}$ of $200 \mathrm{mM}$ L-glutamine (for a final concentration of $2 \mathrm{mM}$ ), $5 \mathrm{~mL}$ of $100 \mathrm{mM}$ sodium pyruvate (for a final concentration of $1 \mathrm{mM}$ ), and $5 \mathrm{~mL}$ of 10,000 $\mathrm{IU} / \mathrm{mL}$ penicillin/streptomycin solution (for a final concentration of $100 \mathrm{IU} / \mathrm{mL}$ ). Store at $4^{\circ} \mathrm{C}$.

Calcium chloride transfection reagent $\left(\mathrm{CaCl}_{2}\right.$ 2.5 M). Dissolve $36.75 \mathrm{~g}$ of calcium chloride dehydrate in $100 \mathrm{~mL}$ MilliQ/PureLab Flex2 water. Sterilize by filtration with a $0.45 \mu \mathrm{m}$ filter (Millipore). Store $1.5 \mathrm{~mL}$ aliquots for up to 6 months at $-20^{\circ} \mathrm{C}$. Working concentrations of $\mathrm{CaCl}_{2}$ are obtained by diluting the stock concentration in deionized tissueculture-grade water (e.g., $80 \mu \mathrm{L}$ of $2.5 \mathrm{M} \mathrm{CaCl}_{2}$ to

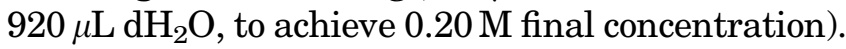

Borate-buffered saline transfection reagent (BBS $2 \times$ ). Dissolve $4.09 \mathrm{~g}$ of $\mathrm{NaCl}, 2.6625 \mathrm{~g}$ of $\mathrm{BES}$, 
and $0.0525 \mathrm{~g}$ of $\mathrm{Na}_{2} \mathrm{HPO}_{4}$; add deionized tissueculture-grade water to reach a volume of $250 \mathrm{~mL}$. Adjust $\mathrm{pH}$ to 6.95 . Sterilize by filtration with a $0.45 \mu \mathrm{m}$ filter (Millipore). Store $14 \mathrm{~mL}$ aliquots for up to 6 months at $-20^{\circ} \mathrm{C}$.

\section{Expanding HEK293T cell line for viral production by reanimation and passaging}

1. Remove a vial of HEK293T expanded master cell line stored at $-20^{\circ} \mathrm{C}$.

2. Thaw at $37^{\circ} \mathrm{C}$ for approximately $2 \mathrm{~min}$.

3. Add $1 \mathrm{~mL}$ of cells to $10 \mathrm{~mL}$ of cell culture medium in a $50 \mathrm{~mL}$ conical tube.

4. Centrifuge two balanced conical tubes at $250 \mathrm{~g}$ for $4 \mathrm{~min}$.

5. Re-suspend cells in $10 \mathrm{~mL}$ of cell culture medium containing $10 \% \mathrm{FBS}$.

6. Count cells with a hemocytometer (for approximately $10^{5}$ cell $/ \mathrm{mL}$ ).

7. Plate $10 \mathrm{~mL}$ of fresh cell culture mediumcontaining cells into a $10 \mathrm{~cm}$ dish or equivalent flask.

8. Place cells in the incubator at $37^{\circ} \mathrm{C}$ and $5 \%$ $\mathrm{CO}_{2}$ overnight.

9. When cells are $70 \%$ confluent, after $1-4$ days, they are ready for passage.

10. Remove the serum-containing medium and rinse with phosphate-buffered saline (PBS).

Note: FBS inhibits the trypsin enzyme, so it must be removed to allow this reaction.

11. Place trypsin-EDTA diluted in dPBS (1:10 or $0.05 \%$ ) onto the cells and watch for signs of dissociation.

Note: Lower concentrations of trypsin may be gentler on the cells, but will require longer incubation times or greater mechanical dissociation.

12. Once cells have dissociated, they can be collected and spun down.

Note: Cells should be further diluted in cell culture medium containing $10 \%$ FBS.

13. The cell pellet should be re-suspended well in approximately $2 \mathrm{~mL}$ of cell culture medium.

14. The cells should then be further diluted in an appropriate volume of cell culture medium to plate the cells at $10^{4}-10^{5}$ cells $/ \mathrm{mL}$.

\section{Optimizing the transfection}

Alternative transfection methods can be used for larger lentiviral vector production volumes. ${ }^{26}$
1. Plate HEK293T cells in four $10 \mathrm{~cm}$ tissue culture dishes.

2. Cells are ready for transfection at $70 \%$ confluence, about $24 \mathrm{~h}$ after plating.

3. Thaw $2 \times \mathrm{BBS}$ and $2.5 \mathrm{M}$ of $\mathrm{CaCl}_{2}$ solutions at room temperature.

4. Prepare different concentrations of $\mathrm{CaCl}_{2}$ $(0.20 \mathrm{M}, 0.25 \mathrm{M}, 0.30 \mathrm{M}, 0.35 \mathrm{M})$ in cell culture-grade $\mathrm{dH}_{2} \mathrm{O}$, by diluting $80 \mu \mathrm{L}$ of $\mathrm{CaCl}_{2}$ in $920 \mu \mathrm{L}$ of $\mathrm{dH}_{2} \mathrm{O}$ and so on.

5. Place $10 \mu \mathrm{g}$ DNA (GFP control plasmid) into each of four conical centrifuge tubes.

6. Add $500 \mu \mathrm{L}$ of diluted $\mathrm{CaCl}_{2}$ per tube.

7. Pipette gently up and down.

8. Add dropwise $500 \mu \mathrm{L} 2 \times \mathrm{BBS}$ per tube.

9. Pipette gently up and down.

10. Let the reaction stand for $30 \mathrm{~min}$ at room temperature in the hood.

11. Add the mixture drop by drop over each dish. Cover the entire area of the dishes.

12. Place cells in the incubator at $37^{\circ} \mathrm{C}$ and $3 \%$ $\mathrm{CO}_{2}$ overnight.

13. Check the fluorescence under the microscope after $24 \mathrm{~h}$.

14. Determine which concentration gives the best transfection efficiency; $>95 \%$ of cells should be green to achieve high levels of viral production.

\section{Plating HEK293T for production of third-generation lentiviral vectors}

Do not allow cells to grow over-confluent prior to viral production; it will lower the titer.

1. To coat plates, prepare $20 \mathrm{~cm}$ dishes or equivalent flasks.

2. Dilute $20 \mathrm{~mL}$ of poly-L-lysine in $80 \mathrm{~mL}$ of dPBS.

3. Pipette $10 \mathrm{~mL}$ of this 1:5 PLL:dPBS solution in each plate $(10 \times 20 \mathrm{~cm})$.

4. Let plates stand for $>15 \mathrm{~min}$ at room temperature in the hood.

5. Aspirate. The plates are now coated. Plate cells immediately after coating.

6. To plate cells, collect HEK293T from confluent plates.

7. Remove media and wash $4 \times 20 \mathrm{~cm}$ confluent plates with $6 \mathrm{~mL}$ of dPBS.

8. Add $4 \mathrm{~mL}$ of Trypsin-EDTA $(0.5 \%)$ to each plate, along with $6 \mathrm{~mL}$ of dPBS. 
9. Incubate at room temperature for $2 \mathrm{~min}$ or until cells start to detach.

10. Add $10 \mathrm{~mL}$ culture medium and collect all cells.

11. Centrifuge two balanced tubes of cells at $250 \mathrm{~g}$ for $4 \mathrm{~min}$.

12. Re-suspend cells in $160 \mathrm{~mL}$ of culture medium.

13. Count cells with a hemocytometer (the target is approximately $5 \times 10^{5}$ cells $/ \mathrm{mL}$ ).

14. Plate $16 \mathrm{~mL}$ of fresh cell culture medium containing cells into each dish. Place cells in the incubator at $37^{\circ} \mathrm{C}$ and $5 \% \mathrm{CO}_{2}$ overnight.

15. Cells are ready for transfection at $70 \%$ confluence, about $24 \mathrm{~h}$ after plating.

\section{Transfecting HEK293T to produce third-generation lentiviral vectors}

Transfection efficiency is a major factor in lentiviral vector yields. Plasmid DNA concentration and quality, cell culture density, and $\mathrm{pH}$ variations of BBS are some of the factors that can affect transfection efficiency. If low transfection efficiency $(<60 \%)$ persists, addition of sodium butyrate within $24 \mathrm{~h}$ post transfection can potentially enhance protein expression levels.

1. Thaw $2 \times \mathrm{BBS}$ and $2.5 \mathrm{M}$ of $\mathrm{CaCl}_{2}$ solution at room temperature.

2. Prepare proper concentration of $\mathrm{CaCl}_{2}$, as previously determined for this batch of reagent.

3. Mix plasmids together, as described in Table 5 .

4. Add $11 \mathrm{~mL} \mathrm{CaCl}_{2}$ to the tube (for $10 \times 15 \mathrm{~cm}$ plates).

5. Pipette gently up and down.

6. Add dropwise $11 \mathrm{~mL}$ of $2 \times \mathrm{BBS}$ to the tube (for $10 \times 15 \mathrm{~cm}$ plates).

7. Pipette gently up and down.

8. Let the reaction stand for $30 \mathrm{~min}$ at room temperature in the hood.
9. Add $2.25 \mathrm{~mL}$ of the mixture into each dish. Cover the entire area of the dishes.

10. Place cells in the incubator at $37^{\circ} \mathrm{C}$ and $3 \%$ $\mathrm{CO}_{2}$ overnight.

\section{Collecting virus-rich supernatants}

- All waste that is possibly contaminated with virus should be inactivated by incubation with disinfectant for $30 \mathrm{~min}$, and all of this waste should be collected in dedicated bags. These bags should be transferred to an autoclave using closed containers and inactivated by autoclaving at $121^{\circ} \mathrm{C}$ for $20 \mathrm{~min}$.

- All autoclaved waste should be incinerated using the appropriate clinical waste route using an approved contractor.

- In the event of spillage of possibly viral vectorcontaminated material, the area will be disinfected using appropriate disinfectant. The used paper towels and any other disposable material should be collected in dedicated bags and autoclaved as above. All work should be performed in a contained area. The wider environment is unlikely to become contaminated. However, a plan should be in place for both a contained spill and uncontained spill (e.g., in an area with high foot traffic). A spill kit should be available in the tissue culture unit and in other areas of use (e.g., the surgery unit if the virus will be used in vivo) for maximal preparedness. Spill response cue cards, with instructions and contact numbers in case of accidental release, should be posted in the manufacturing facilities.

1. After $18 \mathrm{~h}$, replace the culture media with $16 \mathrm{~mL}$ of fresh cell culture medium.

2. Do not collect this transfection media (remove and dispose in appropriate containment).

3. Put cells back in the incubator at $37^{\circ} \mathrm{C}$ and $3 \% \mathrm{CO}_{2}$.

4. After $24 \mathrm{~h}$, remove cell culture medium and place it into four $50 \mathrm{~mL}$ conical tubes. This

Table 5. Plasmid quantities used to achieve transfection for viral production

\begin{tabular}{lcccc}
\hline & DNA mass $(\mu \mathrm{g})$ & DNA length $(\mathrm{bp})$ & DNA copy number & Plasmid volume $(\mu \mathrm{L})$ \\
\hline Transfer vector & 300 & $7,537^{\mathrm{a}}$ & $3.9 \times 10^{13}$ & DNA mass $(\mu \mathrm{g})$ \\
pMDLg/pRRE & 250 & 8,890 & $2.7 \times 10^{13}$ & $2.9 \times 10^{13}$ \\
pRSV-Rev & 125 & 4,180 & $2.5 \times 10^{13}$ & plasmid concentration $(\mu \mathrm{g} / \mu \mathrm{L})$ \\
pMD2.G & 150 & 5,822 & \\
\hline
\end{tabular}

\footnotetext{
${ }^{a}$ The transfer vector length will vary according to the transgene size. When using different plasmid lengths, the DNA copy number should be always maintained as specified above, which can be achieved by increasing or decreasing the DNA mass.
} 
is the first collection of media containing viral vectors.

5. Add $16 \mathrm{~mL}$ of fresh cell culture medium to each plate.

6. Put cells back in the incubator at $37^{\circ} \mathrm{C}$ and $3 \% \mathrm{CO}_{2}$.

7. Centrifuge two balanced tubes of supernatants at $250 \mathrm{~g}$ for $4 \mathrm{~min}$ to remove cell debris.

8. Repeat with two more balanced tubes of supernatants (containing approximately $40 \mathrm{~mL}$ each).

9. Sterile filter the debris-free supernatants using a $0.45 \mu \mathrm{m}$ filter (approximately $160 \mathrm{~mL}$ of supernatant in total).

Note: Viral particles to be used in preclinical applications should be filtered through 0.45 micron filters, although 0.22 micron filters are recommended for GMP manufacturing protocols. Smaller filters improve purity but can lower the viral titer.

10. Label this bottle. Wrap the cap with parafilm. Keep at $4^{\circ} \mathrm{C}$ overnight.

11. Repeat the following day (second collection of media containing viral vectors).

\section{Serial ultracentrifugation for viral vector concentration}

- When following the protocol described here in its entirety, yields of concentrated lentiviral vector reach physical titers between $10^{11}$ and $10^{12}$ particles $/ \mathrm{mL}$ and functional titers between $10^{7}$ and $10^{10}$ particles $/ \mathrm{mL}$. Note that some transgenes may produce cytotoxicity during viral production, resulting in lower viral titers. To overcome this problem, use of an inducible expression system ${ }^{27}$ to control transgene expression during virus production is recommended.

- GMP manufacturing protocol requires nonultracentrifuge-based concentration methods and more extensive filtration (Table 8) such as commercially available tangential flow filtration systems, which could be used to process the GMP viral material.

1. Place conical adaptors into SW28 buckets and SW28 tubes into conical adaptors.

2. Use $30 \mathrm{~mL}$ ultracentrifuge tubes (Beckman).

3 . Place $24 \mathrm{~mL}$ of collected cell culture supernatant in each tube (from day 1 collection).
4. Centrifuge in SW28 at $67,684 \mathrm{~g}$ for $2 \mathrm{~h}$ at room temperature.

5. Discard supernatant and replace tubes into buckets.

6. Place $24 \mathrm{~mL}$ of collected cell culture supernatant in each tube (from day 2 collection).

7. Centrifuge in SW28 at $67,684 \mathrm{~g}$ for $2 \mathrm{~h}$ at room temperature.

8. Discard supernatant and keep tubes inverted.

9. Aspirate media off the edges of tubes.

10. Re-suspend the pellet with $4 \mathrm{~mL}$ of Hank's Balanced Salt Solution (HBSS):

a. Add $2 \mathrm{~mL}$ in the first tube and wash the five subsequent tubes.

b. Add $2 \mathrm{~mL}$ in the first tube and again wash the five subsequent tubes.

11. Load $4 \mathrm{~mL}$ of HBSS on top of $2 \mathrm{~mL}$ of $20 \%$ sucrose in dPBS.

12. Use $6 \mathrm{~mL}$ quick-seal tubes (Beckman). Add HBSS to complete fill.

13. Centrifuge in SW41 at $75,418 \mathrm{~g}$ for $1 \mathrm{~h}$ at room temperature.

14. Discard supernatant and aspirate any remaining media at edge of tube.

15. Re-suspend the pellet gently in $100 \mu \mathrm{L}$ of HBSS. Avoid formation of bubbles.

16. Place viral suspension into a low-bind Eppendorf tube.

17. Re-suspend remaining pellet gently in $100 \mu \mathrm{L}$ of HBSS. Avoid formation of bubbles.

18. Add viral suspension into the same Eppendorf tube ( $200 \mu \mathrm{L}$ total).

19. Seal tube with parafilm.

20. Shake tube on vortex at low speed for $30 \mathrm{~min}$ at room temperature.

21. Spin at $4000 \mathrm{~g}$ for $10 \mathrm{~s}$ to collect the viruscontaining liquid.

22. Make twenty $10 \mu \mathrm{L}$ aliquots of the virus and store at $-80^{\circ} \mathrm{C}$.

\section{Troubleshooting}

Guidance on troubleshooting is given in Table 6.

GMP considerations involving manufacture of lentiviral vectors for clinical use

Premises.

- Premises should be clean, in good repair, for dedicated use, and secure. Conditions such as 
Table 6. Trouble-shooting guide

\begin{tabular}{|c|c|c|}
\hline Problem & Possible reason(s) & Solution(s) \\
\hline Low viral titer & $\begin{array}{l}\text { HEK293T cells are late-passage or over-confluent } \\
\text { Transgene causes toxicity } \\
\text { Non-optimal storage conditions }\end{array}$ & $\begin{array}{l}\text { - Prepare fresh } \mathrm{BBS} 2 \times \text { solution } \\
\text { - Purify fresh plasmids } \\
\text { - Re-determine best } \mathrm{CaCl}_{2} \text { concentration using the same cell line used for } \\
\text { lentivirus manufacture } \\
\text { - Addition of } 6 \mu \mathrm{M} \text { of sodium butyrate up to } 24 \mathrm{~h} \text { after transfection may improve } \\
\text { efficiency } \\
\text { - Only use low passage }(<20) \text { and healthy HEK293T cells, and make sure they are } \\
\text { around } 70 \% \text { confluent on the day of transfection } \\
\text { - Use an inducible expression system to control transgene expression during } \\
\text { - virus production } \\
\text { - Pral preps should be stored at }-80^{\circ} \mathrm{C} \text { and thawed immediately prior to use } \\
\text { - Reanimate a fresh vial of HEK293T and check for adventitious agents } \\
\text { - Purify fresh plasmids } \\
\text { - Check for mycoplasma } \\
\text { - Evaluate aseptic procedures in tissue culture hood }\end{array}$ \\
\hline
\end{tabular}

BBS, borate-buffered saline.

lighting, temperature, and humidity should be controlled within appropriate parameters so as not to affect the medicinal products or starting materials.

- Premises must be designed and controlled to ensure an aseptic environment for manufacturing of ATMPs. GMP procedures and practices must be in place for ATMPs, as sterilization of the finished product is not an option.

- Positive pressure is used to process sterile products for aseptic manufacturing. Pressure cascades should be clearly defined and monitored with alarms.

- Clean areas should be supplied with air which has passed through filters of an appropriate efficiency. Clean air devices should be classified in accordance with ISO 14644-1.

- The Quality Management System of the GMP manufacturing facility must include an emergency plan dealing with accidental release of viable organisms. The plan should describe procedures for containment, ensure the protection of personnel, and describe means of decontamination.

- Offices, restrooms, storage space, and laboratory animal laboratories should be separate from the manufacturing and testing areas. Manufacturing and testing areas should be separate from each other as well, with these procedures carried out by separate personnel.

- Quality control (testing) laboratories must be Good Laboratory Practice (GLP)-approved laboratories for assessing titer, sterility, replication incompetence, and other validation testing. Efficacy tests such as protein expre- ssion and functionality after gene delivery in relevant cells or tissues does not have to occur at GLP grade and can occur in standard academic research labs.

\section{HEK293T producer cells.}

- GMP-grade producer cell lines for viral vector manufacture should be sourced from a suitable facility such as the American Type Culture Collection (ATCC) and maintained as a Master Cell Bank (MCB). The cell line can then be expanded and tested to be used as a certified Working Cell Bank (WCB). Documentation should be provided for receipt and storage of these starting materials.

- Establishment of seed lots and cell banks, including master and working generations, should be performed under appropriate conditions. This should include an appropriately controlled environment to protect the seed lot itself, the cell bank being produced, and the personnel handling these materials.

- During the establishment of the seed lot and cell bank, no other living or infectious material (e.g., viral vectors or cell lines) should be handled in the same area or by the same workers.

- Once a HEK293T cell bank is licensed from ATCC or sub-licensed from a contract manufacturing organization, this resource must be maintained to GMP standards, and must be certified free of mycoplasma and adventitious agents such as bacteria and fungi. Further, this cell line must be validated, including genotyping for identity ver- 
ification and testing for the presence of human viral contaminants.

- Specific considerations for safety during viral manufacture include the risk of biological agents within the HEK293T human-derived cell line used for production, including bloodborne viruses: HIV, hepatitis B virus (HBV), hepatitis $\mathrm{C}$ virus (HCV), and hepatitis $\mathrm{D}$ virus (HDV). These are all dangerous pathogens, which can cause serious or fatal infectious diseases and cancers. HIV causes acquired immune deficiency syndrome (AIDS), while $\mathrm{HBV}, \mathrm{HCV}$, and HDV can cause hepatitis, liver cirrhosis, and cancer. While the HEK293T producer cell line has been used for decades with no known pathogens, the MCB acquired from ATCC and any WCBs derived from it may need further testing to validate the absence of pathogens. These cells can be safely disposed after use, upon exposure to a detergent such as TriGene, which destroys bacteria, fungi, and viruses.

- Documentation should be logged and made available to support traceability, including the number of generations (e.g., passages) between the seed lot or cell bank, the storage conditions, stability data, and recovery logs. These should be consistent with specifications in the marketing authorization/clinical trial authorization, and any deviations should be recorded.

- Cell banks should be stored and recovered in such a way as to minimize the risks of contamination (e.g., stored in sealed vials in liquid nitrogen vapor).

\section{Transfer and packaging plasmids.}

- The transfer vector plasmid contains the gene of interest (the transgene) with expression driven by a promoter sequence. Advice should be requested from the relevant regulatory authority regarding the subtype of lentivector transfer plasmid used. The type of vector used for preclinical studies and clinical-grade manufacture should be the same. The promoter and transgene sequence should be as close as possible to the final version.

- The lentivector transfer plasmid used for preclinical studies may also contain an ampicillin resistance gene or other selection marker for amplification in competent bacteria and other elements necessary for effective infection and gene delivery. Advice should be requested from the relevant regulatory au- thority regarding any restrictions on using a selection marker in the clinical-grade transfer plasmid. Guideline documents from the European Medicines Agency indicate that all beta-lactam antibiotics, such as ampicillin, and streptomycin should be avoided during virus production, as they are known to provoke sensitivity in certain individuals.

- The transfer plasmid often includes a fluorescent reporter gene, separated from the target gene by a cleavage site or internal ribosomal entry site, to identify cells that have been targeted in order to verify the extent of viral transduction. It may be useful to have this reporter tool for preclinical testing, but it is advisable to remove this gene for the purposes of viral manufacture for clinical applications because these proteins may be immunogenic. ${ }^{24}$

- The transfer vector plasmid and the packaging plasmids used for clinical-grade viral vector manufacture should be amplified under GMP conditions. "High-quality" amplification may be suitable for early-phase (e.g., first-in-human) clinical investigation. The plasmids must be certified free of endotoxin and adventitious agents. Further, the transfer plasmid and packaging plasmids should be fully sequence verified.

- Documentation should be logged and made available to support traceability, including the source of the plasmids, any testing conducted on the plasmids, and the storage conditions. These should be consistent with specifications in the marketing authorization/ clinical trial authorization, and any deviations should be recorded.

- The third-generation lentiviral vector system has a major safety advantage compared to previous systems, but this comes with a cost. Lower titers are generally obtained in thirdgeneration compared to second-generation lentivirus manufacture system due to the higher number of separate plasmids (four instead of three, respectively) that must be successfully co-transfected to produce functional particles. Stable inducible packaging cell lines for lentiviral vectors have been proposed to overcome this problem. ${ }^{28,29}$ These cell lines are capable of producing higher amounts of vectors by expressing all lentiviral components at high levels within the cells. This method would also reduce the costs for scaled-up lentiviral manufacture, offering an additional benefit for clinical applications. 
- When changing the components or manufacturing process during a transition to GMP, safety issues must be considered for the altered vector system. It is recommended that such changes occur early during transition to clinical-grade production of the gene therapies, as these can impact costs and regulatory considerations.

\section{Reagents and consumables.}

- Many of the consumables (e.g., flasks or conical tubes) used in preclinical production may not necessarily be suitable for the scaled-up GMP manufacture. However, the standards for consumables may be met by purveyors of commonly used laboratory consumables.

- A GMP-grade reagent sourcing form should be created and used to order items and to record lots received. This process will ensure that raw materials can be traced to facilitate recall of products if necessary.

- Starting materials should be confirmed for release by quality control personnel before use in GMP manufacture. All incoming materials should be checked to ensure the lot corresponds to the order. All materials received must be logged.

- All starting materials should be stored under appropriate conditions and in an orderly fashion to permit batch segregation and stock rotation. Starting materials should be appropriately labeled.

- Labels applied to containers, equipment or premises should be clear and unambiguous. The format of labeling should be consistent throughout the facility and should include status (e.g., quarantined, accepted, or rejected).

- GMP manufacturing procedures must protect the product and the starting materials from the risk of contamination, within the accepted bioburden level described in the marketing authorization or clinical trial authorization.

- Where sterilization of starting materials is required, it should be carried out by heat if possible. Alternatively, other appropriate methods such as irradiation and filtration can be used for inactivation of biological materials.

- If plasmid and/or host-cell DNA persists in the medium, virus-rich supernatants can be treated with bacterially derived DNase or alternatively with Pulmozyme, a human DNase approved for human use by the Food and
Drug Administration. ${ }^{30}$ Pulmozyme treatment would provide a DNase with human rather than animal origin, but could significantly increase the cost of viral vector production and could potentially require an additional step during downstream processing to remove the enzyme.

- Ensure all reagents have a certificate of analysis.

- Ensure all reagents have an EDQM designation (if applicable).

- Ensure all reagents are traceable from point of origin.

- If a reagent has an animal or human origin, additional scrutiny may apply. For example, use of fetal calf serum in cell culture is common, especially for supporting the maintenance of HEK293T cells used for lentiviral and AAV production. However, such humanor animal-derived products must be justified for use in GMP manufacture; suitable origin of materials and traceability standards will apply according to relevant regulatory advice (e.g., the European Pharmacopoeia). It is recommended that non-serum-containing medium is used for GMP purposes.

- As a substitute for small-scale tissue culture flasks or plates, bioreactors can be packed with macroporous microcarriers (e.g., Cytopore, Cytoline) then placed in a continuously stirred tank with circulating medium to achieve serum-free suspension culture.

\section{Instrumentation and equipment.}

- Many preclinical protocols utilize opensystem, small-scale manufacturing. Opensystem manufacturing may be sufficient for producing high-titer lentivirus for a first-inhuman clinical trial. However, it is suggested that high-throughput closed-system manufacturing are generally used for GMP manufacture.

- The equipment (e.g., centrifuges) used in GMP virus production does not have to be certified in any particular way, but it does have to be dedicated to ATMP and not available for any other use.

- Manufacturing equipment must be adequately maintained. Repair and maintenance operations should not present any hazard to manufacturing processes or products themselves. Parts of production equipment that 
come into contact with the product must not react with the product in any way that would affect the quality of the product.

- All equipment must be cleaned to prevent contamination, and cleanings should be documented. Single-use disposable material should be used wherever possible. Sterilization of multi-use equipment in contact with the product must be validated.

- Equipment should be calibrated and/or inspected by appropriate methods at defined intervals to ensure proper performance, and these checks should be documented.

- Defective equipment should, if possible, be removed from production and quality control areas, or at least be clearly labeled as defective.

- Many scaled-up cell culture systems are disposable, single-use bioreactors to achieve closed-system processing. While this presents a significant advantage over flasks (which are limited in scale) or stainless steel containers (which require cleaning), single-use bioreactors have greater cost and environmental impact. In addition, the materials used in any disposables must be validated, including: the potential for leaks, the presence of leachables and extractables, the contact time with biological material, and any changes in risk due to temperature.
- It may be better to make the switch to closedsystem manufacturing early in the translational process, so that process development concerns can be addressed during early phases in the project, and batch testing data can be used to specify the parameters to be met by future batches intended for authorized clinical use.

- Table 7 describes several options for scaledup closed-system manufacturing using bioreactors for the growth of cells and collection of supernatant.

- Table 8 describes several options for tangential flow filtration as a scaled-up GMP-compatible method of purifying and concentrating viral particles.

\section{Manufacturing runs.}

- Prior to beginning a production run, it should be ensured that premises, equipment, and cell lines are in suitable conditions for GMP manufacturing.

- At every stage of processing, products and materials should be protected from microbial and other contamination.

- Generally ATMPs cannot be terminally sterilized. Therefore, manufacturing of the active substance and the finished product is required to be conducted in appropriate condi-

Table 7. Equipment for scaled-up GMP lentiviral manufacture

\begin{tabular}{|c|c|c|c|c|}
\hline Supplier & Model & Features & Advantages & Scale \\
\hline Biotek & 3D Perfusion Bioreactor & $\begin{array}{l}4 \text { independent, autoclavable polycarbo- } \\
\text { nate chambers. Cell culture medias } \\
\text { are perfused through the open porous } \\
\text { structure of scaffolds using a pulsatile } \\
\text { pump. }\end{array}$ & $\begin{array}{l}\text { 3D Insert }{ }^{\mathrm{TM}} \text { scaffolds with various sizes } \\
\text { ranging from } 96 \text {-well to } 6 \text {-well. Can } \\
\text { be used as a single-use bioreactor } \\
\text { system. }\end{array}$ & Small-scale \\
\hline Corning & $\begin{array}{l}\text { CELLSTACK }{ }^{\mathrm{TM}} \text { Culture } \\
\text { Chambers }\end{array}$ & $\begin{array}{l}\text { Cell yields in the } 10^{7}-10^{9} \text { range and are } \\
\text { useful alternatives to multiple roller } \\
\text { bottles or spinner flasks. }\end{array}$ & $\begin{array}{l}\text { A more hydrophilic surface giving more } \\
\text { consistent, even cell attachment, in- } \\
\text { creased cell growth and yields. }\end{array}$ & $200 \mathrm{~mL}, 1 \mathrm{~L}, 2 \mathrm{~L}$, or $8 \mathrm{~L}$ \\
\hline Terumo & Quantum Bioreactor & $\begin{array}{l}\text { This hollow-fiber bioreactor system al- } \\
\text { lows seeding of producer cells on } \\
\text { high-surface areas using small vol- } \\
\text { umes for continuous flow. }\end{array}$ & High yields with a small footprint. & $\begin{array}{l}2.1 \mathrm{~m}^{2} \\
\text { Surface area occupying a total volume of } \\
\quad 180 \mathrm{~mL}\end{array}$ \\
\hline Sartorius & $\begin{array}{l}\mu \text {-bioreactor (small-scale) } \\
\text { to BIOSTAT (large-scale) }\end{array}$ & $\begin{array}{l}\text { Bioreactor platform from cell line devel- } \\
\text { opment to commercial manufacturing. }\end{array}$ & Simple transition between scales. & $15 \mathrm{~mL}$ (MBR) or $2,000 \mathrm{~L}$ (BIOSTAT) \\
\hline Pall & iCELLis & $\begin{array}{l}\text { A closed-system, fully integrated, single- } \\
\text { use, fixed-bed bioreactor, which uses } \\
\text { microcarriers to immobilize continu- } \\
\text { ously perfused cells. }\end{array}$ & $\begin{array}{l}\text { Excellent large-scale production, and } \\
\text { simple transition between scales. No } \\
\text { oxygen sparging required. }\end{array}$ & $\begin{array}{l}1-70 \mathrm{~L} \text { in bioreactor; } 40 \mathrm{~mL} \text { to } 25 \mathrm{~L} \text { in } \\
\text { fixed beds with diameters } 110- \\
860 \mathrm{~mm}\end{array}$ \\
\hline GE & Xcellerex XDR-10 & $\begin{array}{l}\text { A closed-system, fully-integrated, single- } \\
\text { use bioreactor which uses microcar- } \\
\text { riers to immobilize continuously- } \\
\text { perfused cells. }\end{array}$ & $\begin{array}{l}\text { Excellent large-scale production. Auto- } \\
\text { mated data management, low-shear } \\
\text { impeller for gentle efficient mixing of } \\
\text { medium. }\end{array}$ & $\begin{array}{l}\text { 4.5-10 L, available in single, twin, triple, } \\
\text { and quad vessel configuration }\end{array}$ \\
\hline
\end{tabular}


Table 8. Commercially available tangential-flow filtration (TFF) systems for lentivirus particles concentration

\begin{tabular}{|c|c|c|c|}
\hline Supplier & Product & Features & References \\
\hline $\begin{array}{l}\text { GE Healthcare Life } \\
\text { Sciences }\end{array}$ & $\begin{array}{l}\text { UniFlux }^{\mathrm{TM}} \text { system with a } 750 \mathrm{kDa} \text { hollow- } \\
\text { fiber ultrafiltration cartridge }\end{array}$ & $\begin{array}{l}\text { Available in four sizes }(5-600 \mathrm{~L}) \\
\text { Fully automated } \\
\text { Single-use cartridges } \\
\text { Real-time data logging and reporting } \\
\quad \text { function }\end{array}$ & $\begin{array}{l}\text { Merten et al. }{ }^{17} ; \\
\quad \text { Ausubel et al. }{ }^{16}\end{array}$ \\
\hline Spectrum Laboratories & KrosFlo Research II TFF System & $\begin{array}{l}\text { Volumes ranging from } 1 \mathrm{~mL} \text { to } 10 \mathrm{~L} \\
\text { Automated process control and data } \\
\text { collection software }\end{array}$ & Cooper et al. $2011^{31}$ \\
\hline Pall & $\begin{array}{l}\text { Minim with a Centramate LV holder and } \\
\text { a } 100 \text { or } 300 \mathrm{kDa} \text { Omega Screen } \\
\text { channel-cassette }\end{array}$ & $\begin{array}{l}\text { Scalable } \\
\text { Ready-to-use } \\
\text { Semi or full automation }\end{array}$ & Geraerts et al. $2005^{32}$ \\
\hline
\end{tabular}

tions to ensure aseptic manufacturing. For non-sterile raw or starting materials, additional steps may need to be taken to ensure subsequent aseptic manufacturing (e.g., sterile filtration of raw materials or irradiation).

- Measures to prevent cross-contamination appropriate to the risks identified should be put in place. The manufacture of viral vectors and gene therapy medicinal products should be separated spatially and temporally from other products.

- When seeking a contract manufacturing organization as a partner for GMP manufacture of the clinical-grade product, it may be useful to query not only the platform technologies and manufacturing processes used, but also whether any other products are being concurrently manufactured in the same space. These other products may cause concern regarding multiproduct manufacture within the same facility.

- Procedures for maintaining facility infrastructure, logging resources, maintaining equipment, documenting procedures, training staff, practicing waste disposal, reporting to regulatory bodies, and carrying out internal and external audits must be in place prior to production, as well as procedures for quality control and quality assurance.

\section{Virus production.}

- Before any processing operation is started, steps should be taken to ensure that the work area and equipment are clean and free from any starting materials, products, product residues, or documents not required for the current operation.

- Centrifugation of products can lead to aerosol formation and containment of such activities to minimize cross-contamination is necessary.
- The growth-promoting properties of culture media should be demonstrated to be suitable for its intended use. If possible, media should be sterilized in situ. In-line sterilizing filters for routine addition of gases, media, acids or alkalis, anti-foaming agents, and so on to bioreactors should be used where possible.

- Addition of materials or cultures to fermenters and other vessels and sampling should be carried out under carefully controlled conditions to prevent contamination. Care should be taken to ensure that vessels are correctly connected when addition or sampling takes place.

- The gene therapy itself and its clinical application should be described in the Investigational Brochure. Details on manufacturing and testing of the viral gene therapy and the raw materials that go into it (e.g., reagents, plasmids, and producer cell line) should be made available through the Investigational Medicinal Product Dossier (IMPD).

- Many of the reagents used in preclinical lentivirus manufacture are made or sterilized under high-quality conditions, traced from origin, and certified for GMP use. Any human- or animalderived products (e.g., serum-containing media) that are used in gene-therapy production (e.g., with adherent cell cultures) must be justified for use in GMP manufacture. Suitable origin of materials and traceability standards will apply. Alternatively non-serum-containing medium can be used in scaled-up bioreactor settings to achieve high-volume production for GMP purposes.

- For both preclinical and GMP manufacture, HEK293T producer cells can be transiently transfected to allow packaging of the viral vector containing genetic payload. In this protocol, the affordable and efficient method of calcium phosphate co-precipitation is used, 
although other proprietary methods can be used. Stable cell lines used for production must be specified to the regulatory authorities, including any viral vectors used and the raw materials used in their production.

- Ultracentrifugation is commonly used to concentrate lentiviral particles for preclinical applications in gene delivery particularly for in vivo applications. ${ }^{33}$ This is the efficient and easy method for concentrating viral particles for preclinical assays used in this protocol. Alternative protocols such as diafiltration and tangential flow provide options for spin-free protocols to reduce risks to GMP compliance. Tangential flow can be used for purification, concentration, and desalting for GMP purposes.

- The final formulation in which the viral particles are re-suspended may be a buffered salt solution or suitable alternatives. Any use of growth media, supplements, transfection reagents, and resuspension media during manufacture must be documented and justified in the IMPD.

\section{Documentation of procedures and materials}

Documentation allows the recording of quality controls, aids quality assurance, and provides evidence to support batch release. The goal of documentation is to establish, control, monitor, and record all materials and activities which directly or indirectly may affect the quality of medicinal products.

- All calibration and cleaning of equipment and instruments must be documented.

- All handling of materials and products, such as receipt and quarantine, sampling, storage, labeling, dispensing, processing, packaging, and distribution, must be documented.

- All reagents, producer cells, plasmids, and viral vectors must be documented (see Table 9).

- Documentation for manufacturing and testing may be paper-based or electronic, and a data management plan should be in place. Shadow copies allow data to be retrieved if accidentally deleted. Facility management must ensure that any servers containing documentation are housed in temperature-controlled room with restricted access and with redundant power supply. Data should be backed up regularly to a mirrored server in a separate building.

- Batch documentation should be kept for 1 year after expiry of the batch to which it relates or at least 5 years after certification of
Table 9. Process for documenting lentiviral production under GMP

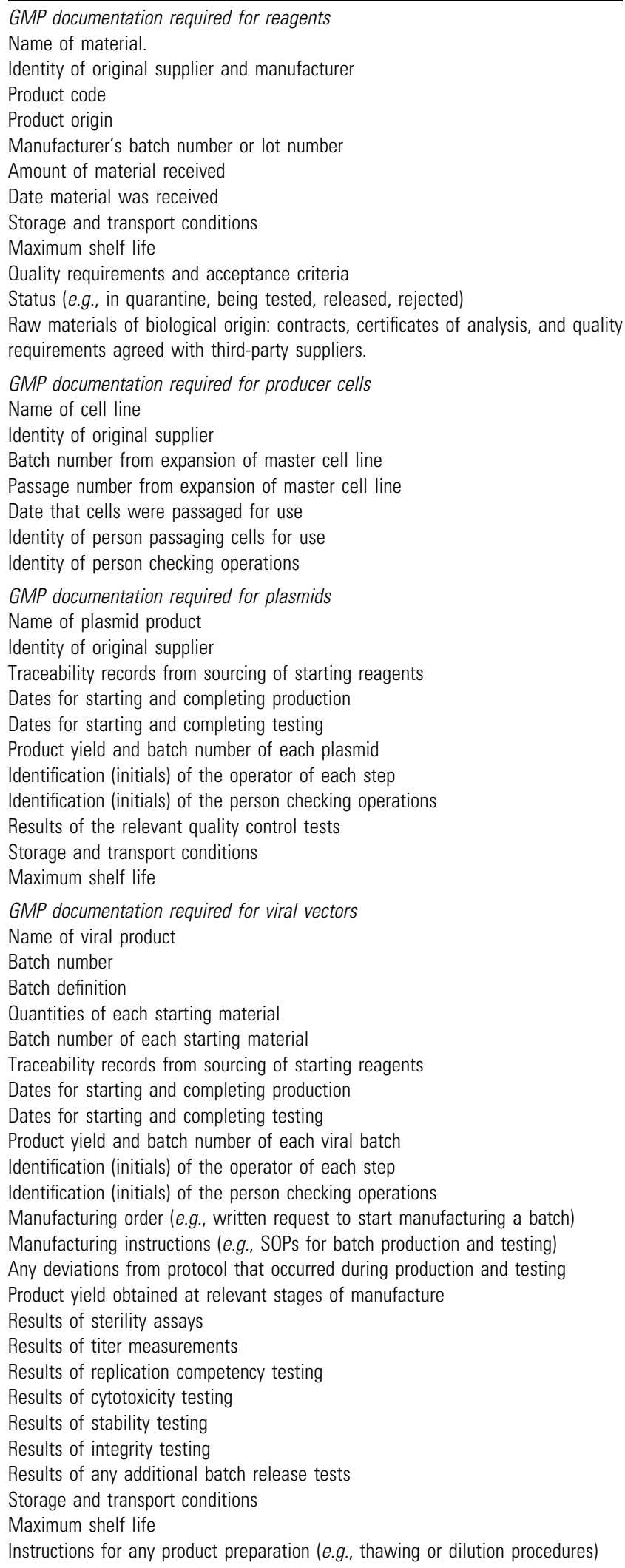


the batch by the QP, whichever is longest. For any investigational medicinal products, the batch documentation must be kept for at least 5 years after the completion or formal discontinuation of the last clinical trial in which the batch was used.

\section{ACKNOWLEDGMENTS}

We thank Professor Didier Trono for providing the plasmids pRSV-Rev, pMD2.G, and
pMDLg/pRRE. This work was supported by the Wellcome Trust and Engineering and Physical Sciences Research Council through an Innovative Engineering for Health grant (CANDO). The authors are grateful to the ATMP Manufacturing Community for linking a network of professionals with expertise in this area.

\section{AUTHOR DISCLOSURE}

No competing financial interests exist.

\section{REFERENCES}

1. Dull T, Zufferey R, Kelly $M$, et al. A thirdgeneration lentivirus vector with a conditional packaging system. J Virol 1998;72:8463-8471.

2. Naldini L, Blomer U, Gallay $P$, et al. In vivo gene delivery and stable transduction of nondividing cells by a lentiviral vector. Science 1996;272:263267.

3. Zufferey R, Dull T, Mandel RJ, et al. Selfinactivating lentivirus vector for safe and efficient in vivo gene delivery. J Virol 1998;72:9873-9880.

4. Stripecke R, Koya RC, Ta HO, et al. The use of lentiviral vectors in gene therapy of leukemia: combinatorial gene delivery of immunomodulators into leukemia cells by state-of-the-art vectors. Blood Cells Mol Dis 2003;31:28-37.

5. Jarraya B, Boulet S, Scott Ralph G, et al. Dopamine gene therapy for Parkinson's disease in a nonhuman primate without associated dyskinesia. Sci Transl Med 2009;1:2ra4.

6. Mansilla-Soto J, Riviere I, Boulad F, et al. Cell and gene therapy for the beta-thalassemias: advances and prospects. Hum Gene Ther 2016;27:295-304.

7. Palfi S, Gurruchaga JM, Ralph GS, et al. Longterm safety and tolerability of ProSavin, a lentiviral vector-based gene therapy for Parkinson's disease: a dose escalation, open-label, Phase 1/2 trial. Lancet 2014;383:1138-1146.

8. Kohn DB, Kuo CY. New frontiers in the therapy of primary immunodeficiency: from gene addition to gene editing. J Allergy Clin Immunol 2017;139: 726-732.

9. Negre 0, Eggimann AV, Beuzard Y, et al., Gene therapy of the beta-hemoglobinopathies by lentiviral transfer of the beta(A(T870))-globin gene. Hum Gene Ther 2016;27:148-165.

10. White M, Whittaker R, Gandara C, et al. A guide to approaching regulatory considerations for lentiviral-mediated gene therapies. Hum Gene Ther Methods 2017;28:163-176.

11. Srinivasakumar N. HIV-1 vector systems. Somat Cell Mol Genet 2001;26:51-81.

12. Burns JC, Friedmann T, Driever W, et al. Vesicular stomatitis virus $\mathrm{G}$ glycoprotein pseudotyped ret- roviral vectors: concentration to very high titer and efficient gene transfer into mammalian and nonmammalian cells. Proc Natl Acad Sci U S A 1993; 90:8033-8037.

13. Kutner RH, Zhang $X Y$, Reiser J. Production, concentration and titration of pseudotyped HIV-1based lentiviral vectors. Nat Protoc 2009;4:495505.

14. Marino MP, Luce MJ, Reiser J. Small- to largescale production of lentivirus vectors. Methods Mol Biol 2003;229:43-55.

15. Merten OW, Hebben M, Bovolenta C. Production of lentiviral vectors. Mol Ther Methods Clin Dev 2016; 3:16017.

16. Ausubel LJ, Hall C, Sharma A, et al. Production of CGMP-grade lentiviral vectors. Bioprocess Int 2012; 10:32-43.

17. Merten OW, Charrier S, Laroudie N, et al. Largescale manufacture and characterization of a lentiviral vector produced for clinical ex vivo gene therapy application. Hum Gene Ther 2011;22:343-356.

18. Pincha M, Sundarasetty BS, Salguero G, et al. Identity, potency, in vivo viability, and scaling up production of lentiviral vector-induced dendritic cells for melanoma immunotherapy. Hum Gene Ther Methods 2012;23:38-55.

19. Huang J, Khan A, Au BC, et al. Lentivector iterations and pre-clinical scale-up/toxicity testing: targeting mobilized CD34+ cells for correction of Fabry disease. Mol Ther Methods Clin Dev 2017;5: 241-258.

20. Sheu J, Beltzer J, Fury B, et al. Large-scale production of lentiviral vector in a closed system hollow fiber bioreactor. Mol Ther Methods Clin Dev 2015;2:15020

21. Sundarasetty BS, Chan L, Darling D, et al. Lentivirus-induced "Smart" dendritic cells: pharmacodynamics and GMP-compliant production for immunotherapy against TRP2-positive melanoma. Gene Ther 2015;22:707-720.

22. Sundarasetty BS, Kloess S, Oberschmidt 0, et al. Generation of lentivirus-induced dendritic cells under GMP-compliant conditions for adaptive immune reconstitution against cytomegalovirus after stem cell transplantation. J Transl Med 2015; 13:240.

23. Pear WS, Nolan GP, Scott ML, et al. Production of high-titer helper-free retroviruses by transient transfection. Proc Natl Acad Sci U S A 1993;90: 8392-8396.

24. Stripecke R, Carmen Villacres M, Skelton D, et al. Immune response to green fluorescent protein: implications for gene therapy. Gene Ther 1999;6: 1305-1312

25. Cronin J, Zhang XY, Reiser J. Altering the tropism of lentiviral vectors through pseudotyping. Curr Gene Ther 2005;5:387-398.

26. Witting SR, Li LH, Jasti A, et al. Efficient large volume lentiviral vector production using flow electroporation. Hum Gene Ther 2012;23:243-249.

27. Gossen M, Freundlieb S, Bender G, et al. Transcriptional activation by tetracyclines in mammalian cells. Science 1995;268:1766-1769.

28. Farson D, Witt R, McGuinness R, et al. A newgeneration stable inducible packaging cell line for lentiviral vectors. Hum Gene Ther 2001;12:981-997.

29. Sanber KS, Knight SB, Stephen SL, et al. Construction of stable packaging cell lines for clinical lentiviral vector production. Sci Rep 2015;5:9021.

30. Shaw A, Bischof D, Jasti A, et al. Using Pulmozyme DNase treatment in lentiviral vector production. Hum Gene Ther Methods 2012;23:65-71.

31. Cooper AR, Patel S, Senadheera, et al. Highly efficient large-scale lentiviral vector concentration by tandem tangential flow filtration. J Virol Meth 2011;177: 1-9.

32. Geraerts $M$, Michiels $M$, Baekelandt V, et al. Upscaling of lentiviral vector production by tangential flow filtration. J Gene Med 2005;7: 1299-1310.

33. Ichim CV, Wells RA. Generation of high-titer viral preparations by concentration using successive rounds of ultracentrifugation. J Transl Med 2011;9:137.

Received for publication June 14, 2017; accepted after revision November 17, 2017.

Published online: December 7, 2017 